\title{
Okul Öncesi Eğitim Alan Beş Yaş Çocuklarının Meslek Seçimleri ve Cinsiyetlerine İlişkin Düşüncelerinin İncelenmesi
}

\section{Zeynep TEMIZ*, Şenil ÜNLÜ-ÇETİN**, Simge YILMAZ***}

Öz: Bu nitel çalışma okul öncesi eğitim almakta olan 5 yaşındaki çocukların kendi cinsiyetlerini değerlendirme biçimlerini ve meslek seçimlerini ortaya koymak amaciyla gerçekleştirilmiştir. Çalışmaya Doğu Anadolu Bölgesi’ndeki merkez bir ilin dezavantajlı bir bölgesinde yaşayan ve MEB'e bağlı bağımsız anaokullarında eğitim gören 5 yaşındaki 24 kız ve 26 oğlan çocuğu katılmıştır. Çalışmanın sonuçları çocukların cinsiyet algılarının yaşadıkları toplumda cinsiyetle ilgili var olan kalıp yargılarla oldukça benzer olduğunu göstermiştir. Çalışmanın sonuçları, kız çocukların cinsiyet tanımlamalarının dış görünüş/fiziki özelliklere, oğlan çocuklarının cinsiyet tanımlamalarının ise daha çok yaptıkları etkinlikler ya da davranışlar üzerine olduğunu ortaya koymuştur. Çalışmaya katılan kız çocuklarının yaşadıkları toplumda gözlemledikleri işleri gelecekte meslek olarak yapmak istedikleri (bulaşık yıkamak, temizlikçi olmak vb.), oğlan çocuklarının ise asker, polis ve şoförlük gibi maskülen özellikleri baskın meslekleri yapmak istedikleri gözlemlenmiştir.

Anahtar Kelimeler: Okul öncesi eğitim, Cinsiyetçi kalıp yargılar, Toplumsal cinsiyet rolleri, Toplumsal cinsiyet eşitliği

\footnotetext{
* Doç. Dr. Zeynep Temiz Karamanoğlu Mehmetbey Üniversitesi, ORCID: 0000-0002-4436-9737, ztemiz@kmu.edu.tr

** Dr. Öğr. Üyesi Şenil Ünlü-Çetin Kırıkkale Üniversitesi, ORCID: 0000-0001-9898-1609, senilunlucetin@gmail.com

*** Ar.Gör.Dr. Simge Y1lmaz Mersin Üniversitesi, ORCID: 0000-0002-5092-8670, smgylmz21@,gmail.com
} 


\title{
Investigating Preschoolers' Career Aspirations and Views of Their Genders
}

\begin{abstract}
This qualitative description aims to examine the pre-school children's gender stereotypes and their choice of profession that they plan to have in future influenced by gender stereotypes. 50 (24 girls and 26 boys) 5 years-old children who were attending public preschools and coming from low socio-economic status families participated in this study. Findings of this study revealed that children's perception was influenced by gender stereotypes in society. Generally, girls associated their gender with physical appearance. Girls attributed themselves passive skills such as being mother, helping mother and doing chores. While boys attributed themselves more active skills like driving and working. Children's choice of profession for future was also affected from culture. Girls mostly choose being teacher which is mainly performed by women in society. Similarly, boys declared that they would like to become a police-officer and soldier which are characterized to men in society.
\end{abstract}

Key words: Pre-school education, Gender stereotypes, Social gender roles, Social gender equity

\section{Giriş}

Bir bireyin dünyaya geldiği andan itibaren sahip olduğu birçok rolü vardır. Bu sosyal rollerin bazıları bireyin yaşamını, davranışlarını, düşünce yapısını şekillendirecek güce sahiptir (Ghouri ve Abrar, 2010). Bu rollerin en önemlilerinden biri toplumsal cinsiyet rolleridir. Eril ya da dişi olmayla ilgili olan biyolojik cinsiyetten farklı olarak toplumsal cinsiyet, erkek ya da kadın bireylerin yaşadıkları toplumda nasıl davranması, nasıl düşünmesi ve hatta nasıl hareket etmesi gerektiği ile ilgili olan yargılardır. Yani kadın ya da erkek olmak biyolojik özellikler ile ilgili iken, kadınlık ve erkeklik, yani kadın ve erkek olmaya ilişkin roller ve özellikler, toplumsaldır (Hepşen, 2010). Neredeyse tüm toplumlarda yaygın olarak görülen geleneksel toplumsal cinsiyet rolleri kadına ev işlerini ve çocuk bakımını sağlama rollerini uygun görürken; erkeğe güçlü olmak ve evini geçindirmek gibi rolleri atfetmiştir (Adler, Kless \& Adler, 1992). Toplumların cinsiyet algısı ideolojik kabul edilebilir ve bu ideolojinin gölgesinde eğitim alan, yaşayan ve çalışan insanların inanışları ve davranışları bu ideolojinin beklentilerine cevap verecek şekilde şekillenir (Kalan, 2010). Cinsiyetçi kalıp yargılar diğer 
bütün kalıp yargılarda olduğu gibi insanların günlük hayata dair gözlemlerine dayanır. Sürekli olarak bir grup insanın belli bir eylemi yerine getirdiğini gözlemleyen birey, bu eylemi yerine getirebilmek için gerekli olan yeteneklerin ve kişilik özelliklerinin o gruba ait olduğuna inanır. Örneğin, sürekli kadınları çocuk bakımıyla ilgilenirken gören birey, çocuk bakımı için gerekli olan sıcaklık ve sevecenlik gibi özelliklerin kadınlara özgü olduğuna inanmaya başlar (Eagly \& Steffen,1984).

Toplumsal cinsiyet rolleri doğuştan olmadığı, kültürel yapı içinde edinildiği için değiştirilebilir. Ancak, anne ve babalar çocuklarına toplumun beklentisi ile uyumlu ve çocuğun biyolojik cinsiyetine uygun davranışları kazandırma eğilimindedir. Sosyokültürel ve sosyoekonomik koşullara göre farklılık gösterse de arkadaşlar, okul, kitaplar, şarkılar, filmler, televizyon kanalları gibi etmenler cinsiyete yönelik geleneksel kalıp yargıların oluşmasında ve daha da güçlenmesinde etkin rol oynamaktadır (Yağan-Güder \& Güler-Yıldız, 2016). Ancak aileden hemen sonra bireyin toplumsal cinsiyet rollerine ilişkin algısını şekillendiren en önemli kurumlar eğitim kurumlarıdır. Eşitlikçi toplumsal cinsiyet rollerine sahip olma durumu yüksek eğitim düzeyi ve yüksek sosyo-ekonomik statü ile yakından ilişkilidir (Beşpınar, 2014).

Okul öncesi eğitim bireylerin eğitim sistemine dahil olduğu ilk basamaktır. Ailede gerçekleşen sosyalleşme süreci, okul öncesi eğitime dahil olmayla birlikte yeni bir döneme girmektedir. Okul öncesi eğitimin hitap ettiği yaş grubu olan 0-6 yaş, toplumsal cinsiyet rollerinin şekillendiği bir süreçtir (Erden, 2009; Gooden \& Gooden, 2001; Martin ve Ruble, 2004; Şahin, Çoban \& Korkmaz, 2016; Temiz \& Cin, 2017; Yağan Güder, 2014). Bu süreçte çocuklar önce biyolojik cinsiyetlerini ardından ise toplumsal cinsiyet rollerine ilişkin normları fark etmektedirler. $\mathrm{Bu}$ nedenle hem aile hem de okul öncesi eğitim sisteminde edinilen toplumsal cinsiyet rollerinin, çocuğun gelecekte sahip olacağı toplumsal cinsiyet algısına etki etmesi beklenmektedir.

Türkiye' de eğitim, siyaset, aile gibi sosyal yapılarda ve çalışma gücüne katılım gibi durumlarda yaygın olarak var olan tablo, geleneksel toplumsal cinsiyet algısının daha yaygın olduğuna işaret etmektedir (Bingöl, 2014).

Bu çalışmanın amacı, okul öncesi eğitimi almakta olan beş yaş grubu çocukların kendi cinsiyetlerini nasıl tanımladıklarını ve bu tanımlamaların gelecekte seçmeyi istedikleri 
mesleklere nasıl yansıdığını ortaya koymaktır. Bu amaç doğrultusunda mevcut çalışma iki temel araştırma sorusuna yanıt aramaktadır. Bunlar;

1) Okul öncesi eğitim alan 60 aylık çocuklar kendi cinsiyetlerini nasıl tanımlamaktadırlar?

2) Okul öncesi eğitim alan 60 aylık çocuklar gelecekte hangi mesleği yapmak istemektedirler?

\section{Cinsel Kimlik}

Cinsel kimliği bir kişinin kadın ya da erkek olması olarak tanımlarız (Zucker \& Bradley, 1995). Birey kendisini kadın ya da erkek olarak nitelendirdikten sonra artık bu bir sosyal kategori halini alır çünkü kendimizi bir cinsiyet grubuna dahil ederek tanımlamış oluruz (Thoits \& Virshup, 1997). Bu sosyal kategorileri ve hangi kategoriye ait olduklarını anlamaya başlamak, çocukların gelişimlerinde bir kilometre taşı kabul edilir. Çocuklar kendilerini cinsiyetlerine göre kategorilemeyi oldukça küçük yaşlarda öğrenirler. Çocuklar 18-24 aylıkken sözel olmayan yollarla cinsiyet kimliğini kazanmaya başladıklarının ilk işaretlerini veriler. 2730 aylık olduklarında ise kendi cinsiyetlerini doğru olarak belirtebilirler. Beş yaşına gelen çocuklar artık cinsiyet rollerine dair temel bilgilere sahip olmuşlardır (Halim \& Ruble, 2010).

Cinsiyet kavramını öğrenirken çocuklar 3 aşamadan geçerler. İlk olarak çocuklar kendini kız ya da oğlan olarak doğru bir şekilde tanımlamalıdırlar. İkincisi çocuklar cinsiyetin sabit olduğunu kavramalıdırlar yani cinsiyetin zaman içinde aynı kaldığını anlamalıdırlar. Buna göre kız bir bebeğin büyüdüğünde kadın aynı şekilde oğlan bir bebeğin ise büyüdüğünde bir erkek olacağını bilirler. Son olarak çocuklar cinsiyet tutarlılığını kazanırlar. Cinsiyet tutarlılığı yüzeysel değişiklikler yapılsa da cinsiyetin aynı kaldığının anlaşılması demektir. Örneğin, bir erkek elbise giyse de hala erkektir (Slaby \& Frey, 1975).

Cinsel kimlik ve cinsiyetçi kalıp yargılar yaşam boyu ele ele gelişmektedirler. Peki çocuklar ne tür kalıp yargılar geliştirirler? 26 aylıktan itibaren çocuklar yetişkinlerin cinsiyet farklılıklarının farkına varmaya başlarlar. Yetişkinlerin dış görünüşleri, sahip oldukları şeyler ve rollerin yanı sıra somut olmayan özelliklerini de ayırt edebilirler. 31-32 aylıkken oyuncaklar hakkında kalıp yargıları fark edebilirler (Ruble \& Martin, 1998). Devamında 5 yaşına geldiklerinde iki cinse atfedilen kibarlık ya da maceracılık gibi kişilik özellikleri hakkında bilgi sahibi olmaya başlarlar (Powlishta, Sen, Serbin, Poulin-Dubois, \& Eichstedt, 2001). Çocuklar 
kızların ve oğlanların nasıl olduğunu tanımlarken kızları genellikle dış görünüşe ait olan terimlerle tanımlarlar mesela elbise, takı, saç ve parfüm gibi. Tam tersine oğlanı tanımlarken eylem ve davranış içeren terimlerle tanımlamaya meyillidirler mesela güreşme, kavga etme ve itme gibi. $\mathrm{Bu}$ nedenle çok küçük yaşlardan itibaren ebeveynler dâhi kız çocuklarının görünüşlerine, oğlan çocuklarının ise davranışlarına vurgu yaparlar. Hatta ebeveynlerin çocuklarıyla olan konuşmaları incelendiğinde de durum aynı şekilde çıkmaktadır (Cristofaro \& Tamis-LeMonda, 2008).

\section{Feminist Teori ve Ĕgitim}

Feminizm, Latincede kadın anlamına gelen femine kelimesinden üremiş bir kavramdır (Taş, 2016). Feminizm, temelde kadın ve kadının toplumsal statüsü ile ilgilenir ve " kadın-erkek ayrımcılığına karşı durarak, karşı cinler arasında türlü ekonomik, siyasal, sosyo-kültürel ve toplumsal eşitliğì" savunur (Taş, 2016: 165). Literatürde birçok farklı tanımı olsada en yaygın olarak kullanılan tanımlardan biri Mitchel'e (1995) aittir ve feminizmi "kadınların kendi aralarında bir dayanışma yaratarak, erkek egemen dünyanın norm ve değerlerine, cinsiyetçi politikalarına karşı başlatmış olduğu mücadele" şeklinde betimlemektedir (ss.6-7). En temelde feminizm, kadın ve erkekler arasında var olan biyolojik farklılıkların toplumdaki kadın erkek ayrımcılığına sebep olacak kadar önemli olmadığını, toplumun erkeklik ve kadınlığa yüklediği farklı anlamlar nedeniyle kadınlar ve erkekler arasındaki ayrımcılığın kadınların aleyhine eğitim başta olmak şartıyla siyaset, aile yaşantısı, iş gücüne katılım gibi yaşamın her alanında kendini gösterdiğini dile getirir (Taş, 2016). Bu bağlamda feminist yaklaşımın temel amac1, erkek ve kadın arasındaki eşitsizlikleri tamamen yok etmek ve erkeği egemen kadını ise ikincil konuma getiren toplumsal yapıyı cinsiyetsiz bir yapıya dönüştürmektir (Özdemir \& Aydemir, 2019). Feminizm günümüzde dört farklı zaman diliminde gerçekleşen değişimlerle ele alınmakta her bir zaman diliminde-dalga- feminizmin farklı bir alandaki cinsiyet eşitsizliğine odaklandığı gözlemlenmektedir. Birinci dalga feministler, kadın erkek arasındaki eşitsizlikleri eğitim ve oy hakkı gibi temel haklarda ele alırken (Özdemir \& Aydemir, 2019); ikinci dalga feminizmde daha çok örgütsel bağlamda kadın ve erkekler arasındaki eşitsizlikler ve bu eşitsizliklerin temelinde yatan nedenler üzerine durulmuş ve kadının sadece kadın olarak doğmasından dolayı toplumsal yapıda ikincil konuma getirilmesine ciddi bir eleştiri getirilmiştir (Nalbant \& Korkmaz, 2019). Üçüncü dalga feminizm, daha çok bireysel kimlik 
üzerine odaklanmış, kadın sorunlarının genellenemeyeceğini aksine farklı kültür, ırk ve coğrafyalarda kadınların farklı sorunlar yaşadığını ileri sürmüştür ve son olarak dördüncü dalga feminizmde (ekofeminizm) kadınlık ve doğa ilişkisi üzerine durulmuş, erkek egemen yapının doğayı tahrip ettiğine vurgu yapılmıştır (Özdemir \& Aydemir, 2019). Birinci dalga feminizm hareketi kadınların eğitim ve oy verme gibi temel/doğal haklarını elde etmeleri ile sonuçlanırken (Örs, 2016), ikinci dalga feminizm toplumsal cinsiyet kavramının ortaya çıkmasında etkili olmuştur (Koray, 2011).

\section{Toplumsal Cinsiyet}

Cinsel kimlik doğuştan gelen ve biyolojik olarak kromozomlar, cinsel hormonlar ve üreme organları ile belirlenen cinsel özelliklerdir. Toplumsal cinsiyet ise kişinin yaşadığ toplum ve kültür tarafından şekillendirilir. Diğer bir deyişle, "kadın ve erkek olmak, doğal ve doğuştan olarak adlandırılırken, kadınlık ve erkeklik ise toplumsallaşma süreci ile beraber kültürel bir yapılanmaya işaret etmektedir” (Hepşen, 2010: 14). Toplumsal cinsiyet rolleri insanların duygu, düşünce, ilişki kurma tarzı, tutum, giyim-kuşam gibi günlük yaşantılarda içinde yaşanılan toplumun erkekten ve kadından sergilemesini beklediği cinsiyete uygun rollerin tamamıdır. Daha öz bir deyişle, toplumsal cinsiyet kadınla erkeğin sosyal ve kültürel açıdan tanımlanmasıdır. Toplum bu iki cinsi birbirinden ayırt etmek için salt biyolojik farklılıkları değil bu biyolojik farklılıklara atfettiği kendine öz beklenti, algı, değer ve yargılarını kullanır (Ecevit \& Karkıner, 2011). Toplumun kadın ve erkeğe uygun gördüğü davranış, tutum, hak, görev ve yükümlülükler toplumsal cinsiyet rolü olarak kabul edilir (Cin, Karlıdağ-Dennis, \& Temiz, 2020; Dökmen, 2014; Ecevit, 2010; Zeyneloğlu, 2008). Kadın ve erkeklerin nasıl görüneceği, davranacağı ya da konuşacağına dair ortak bir inanış aşılayan kültür toplumsal cinsiyet rollerinin üreticisidir (Güler-Yıldız, 2016; Yağan-Güder). Yani kültür toplumsal cinsiyet kalıplarının oluşmasında ve pekişmesinde rol oynayan en önemli etmenlerden biridir.

Salt biyolojik özelliklerine dayanarak kız ya da oğlan olarak doğan bireyler, toplumun nasıl davranılacağına, nasıl düşünüleceğine hatta nasıl hareket edilmesi gerektiğine dair sahip olduğu beklentilere dayanarak (Akın \& Demirel, 2003) kız ve oğlan çocuk, kadın ve erkek, anne ya da baba olmaya yönlendirilirler (Terzioğlu \& Taşkın, 2008). 
Bunun sonucu olarak bireyin içinde yaşadığı toplumun cinsiyetlere ilişkin algısı, bireyin kendini erkek ya da kadın olarak nasıl tanımladığı ve bu tanımla tutarlı olarak nasıl davrandığının ayrılmaz bir parçası haline gelmektedir (Fincancığlu \& Bulut, 2008).

Beşpınar (2014), aile içinde gerçekleşen iş bölümünün toplumsal cinsiyet rolleri dışında herhangi başka bir olguyla açıklanmasının oldukça zor olduğunu ifade etmektedir. Diğer bir deyişle, toplumsal cinsiyet rollerine ilişkin algının en belirgin olarak gözlemlendiği kurum aile ve bu ailede gerçekleşen iş bölümüdür. Beşpınar (2014) tarafından gerçekleştirilmiş olan ve 2006- 2011 yıllarında ülke genelinde elde edilen istatistiklerle aile yapısını toplumsal cinsiyet bağlamında incelemeyi amaçlayan çalışma da, geleneksel toplumsal cinsiyet rollerine dayanan aile içi iş bölümünün kırda yaşayan ailelerde daha fazla gözlemlendiği; kentte ise geleneksel cinsiyet rollerinin varlığını sürdürmesine rağmen kırdaki aile yapısına göre daha eşitlikçi bir durumda olduğu ortaya çıkmıştır. Beşpınar (2014), bir bireyin cinsiyet ve yaşa bağlı eşitsizlikleri deneyimlediği ve öğrendiği ilk kurumun aile olduğunu vurgulamıştır. Cunningham (2001) tarafından gerçekleştirilen bir çalışmada, yetişkinlerin evdeki iş bölümü davranışlarını yordayan en önemli faktörün, kendi anne ve babalarının işleri nasıl bölüştüğüne dair deneyimleri olduğunu bulunmuştur. Bu çalışmaya göre, eşitlikçi iş bölümünü benimseyen yetişkinlerin ailelerinde de eşitlikçi bir iş bölümünün olduğu bulunmuştur. Amato ve Fowler (2002) da toplumsal cinsiyet rollerinin ilk önce ailede öğrenilmeye başladığını ardından da sosyalleşme sürecinde bu öğrenimin devam ettiğini öne sürmüştür.

Okul öncesi eğitim bireylerin toplumsal cinsiyet rollerine ilişkin algılarının şekillenmeye başladığı önemli bir eğitim basamağıdır. Çocuklar geliştikçe cinsiyet rollerini ve kız ya da oğlan olmanın ne demek olduğunu araştırmaya başlarlar. Cinsiyet rollerine ilişkin görüşlerin nasıl değiştiğini inceledikleri araştırmalarında Miller, Lurye, Zosuls, ve Ruble (2009), 5-7 yaşlarında cinsiyet rollerine ilişkin sahip olunan keskin görüşlerin, 3-6 yıl sonra sahip olunan cinsiyet rol algılarındaki keskinliği yansıttığını göstermiştir. Gelişimsel olarak, 57 yaşında en keskin dönemini yaşayan cinsiyet rol algısının, ilerleyen yaşlarda biraz daha esneyebildiği düşünüldüğünde (Blakemore, 2003), bu yaş grubu çocuklarda var olan cinsiyet rollerine ilişkin görüşleri ortaya çıkarmak, eğitimin ilerleyen kademelerinde çocukların sahip oldukları görüşleri değiştirme sürecinde kullanılabilecek teknikleri belirlemek adına önemli bir adımdır. Ek olarak, Halim ve Ruble (2010) yaptıkları alan yazın taraması sonucunda, 5-7 yaş 
grubundaki çocukların cinsiyet normlarına ilişkin sahip oldukları düşüncelerin, çocukların hem öz-değerlerine ilişkin görüşlerini hem de düşünme ve davranış biçimlerini etkilediğini ortaya koymuştur. Bu durum, çocuklarda var olan cinsiyet normlarına ilişkin görüşleri öğrenmenin onların davranış ve düşünüş biçimlerini anlamada da yardımcı olacağını göstermektedir. Tüm bu özellikler düşünüldüğünde, Türkiye'nin doğu bölgesinde yaşayan ve okul öncesi eğitim alan beş yaş grubu çocukların kendi cinsiyetlerini nasıl tanımladıklarını anlamayı ve gelecekte yapmak istedikleri mesleklere ilişkin düşüncelerini ortaya koymayı hedefleyen bu çalışmanın ilgili alan yazına katkıda bulunacağı düşünülmektedir.

\section{Kariyer Tercihi}

“Büyüyünce ne olacaksın?” sorusu, özellikle erken çocukluk yıllarında yetişkinlerin çocuklara, eğlence amaçlı sordukları sorulardandır. Erken çocukluk döneminde bu soruya verilen yanıtların çoğu zaman çocukların geçici heveslerini yansıttığı düşünülerek çok da ciddiyetle ele alınmamaktadır (Chambers, Kashefpakdel, Gore vd., 2016; Rehill \& Percy, 2018). Ancak alan yazındaki çalışmalar, bireylerin kariyer tercihlerinin erken yıllarda şekillendiğini ortaya çıkarmaktadır. Kariyer seçimine ilişkin temel birçok boyut, çocuk daha formal eğitime başlamadan gerçekleşir ve bu boyutların değişme ihtimali de oldukça düşüktür. Bunun en temel nedenlerinden biri, erken çocukluk döneminde yetişkinlikte yapılabilecek mesleklere ilişkin algının gelişmesidir (Champers vd., 2018). Yapılan birçok çalışma, kadın ve erkeklerin başarılı olabileceklerini düşündükleri meslek gruplarında önemli farklılıklar olduğunu ortaya çıkartmış ve bu düşünüş biçimlerinin gelecek nesillere aktarıldığı argümanını ileri sürmüştür (Akerlof \& Kranton, 2000; Breen \& Garcia-Penalosa, 2002). Kariyer tercihi ya da meslek tercihi, çocukların "bana benzeyen diğerleri neler yapıyor?" gözleminin sonucunda oluşmaktadır ve bireyler yapabilecekleri hakkında birçok kalıp yargıyı edinmiş olarak formal eğitime başlamaktadır (Chambers vd., 2018; Gottfredson, 2002). 4-14 yaş aralığında çocuklar için, çocukların boyutunda inşa edilmiş bir şehir olan ve farklı iş alanlarını çocukların deneyimlemesine olanak tanıyan KidZania'da gerçekleştirilen bir çalışmada, cinsiyetin çocukların seçimlerini etkilediği ortaya konmuştur. Erkeklerin mühendislik ve spor koçluğu, kızların ise güzellik uzmanı ya da model olmak istediklerini ortaya çıkmıştır. Yine aynı çalışma, 14 yaşındaki çocukların yaptıkları tercihlerin dört yaş çocuklarının yaptıkları tercihlere çarpıcı bir şekilde benzediğini göstermiştir (Chambers vd., 2018). 
Benzer bir şekilde, 61.000 ilkokul çocuğu ile yaptıkları çalışmada Chambers ve diğerleri (2018) katılımcı çocuklardan gelecekte yapmak istedikleri mesleği çizmelerini istemiş ve onlara bu mesleği nereden duyduklarını sormuştur. Çalışmanın sonuçları, gelişmekte olan ülkelerdeki çocukların seçtikleri mesleklerin daha çok doktorluk, öğretmenlik olduğunu, sosyo-ekonomik statünün meslek seçimlerini etkilediğini, çocukların meslek seçimlerini etkileyen en önemli unsurların anne-babaları ve yakın akrabaları olduğunu göstermiştir. Aynı çalışmada cinsiyet, çocukların meslek seçimlerini etkileyen önemli bir unsur olarak tespit edilmiş; kız çocuklarının daha çok öğretmen, oğlan çocuklarının ise daha çok asker ya da polis olmak istedikleri ortaya konmuştur.

Mevcut çalışma, Chambers ve diğerlerinin (2018) gerçekleştirmiş olduğu bu çalışmadan yola çıkarak dizayn edilmiştir. Drawing Future (Geleceği Çiz) isimli bu projede, ilkokul düzeyinde çocuklar örnekleme dahil edilmiştir. Ancak daha önce de belirtildiği gibi, çocukların cinsiyete bakış açıları ve cinsiyetlere ilişsin toplum tarafından kabul gören davranış modelleri çok daha öncesinde, erken çocukluk yıllarında şekillenmeye başlamaktadır. Alan yazınında okul öncesi dönem çocukları ile yapılmış böyle bir çalışmaya rastlanılmamış olması, gündelik diyaloglarda sıkça sorulan “Büyüyünce ne olacaksın? /Ne olmak istersin?” sorusunun bilimsel açıdan değerlendirilecek düzeyde ciddiye alınmadığı şeklinde yorumlanmıştır. Bu nedenle, mevcut çalışma alandaki bu boşluğu doldurmayı amaç edinmiştir.

\section{Yöntem}

\section{Araştırma Deseni}

Sandelowski (2000) temel amacı katılımcılardan alınan bilgiyi olduğu gibi, öznel yorumlara uğratmadan, ortaya koymayı amaçlayan nitel araştırmalar için betimleyici nitel araştırma tanımını yapmıştır (Sandelowski, 2000). Betimleyici nitel araştırmanın amacı, araştırılan olguya yönelik katılımcıların tanımlamalarındaki öze ulaşmak değil, katılımcıların görüşlerini araştırmacının süzgecinden geçirmeden olduğu gibi ancak daha özet ve anlaşılır bir biçimde aktarmaktır (Sandelowski, 2000). Bu çalışmada da, çocukların cinsiyetlerine yönelik algılarını ve meslek seçimlerini ortaya koymak amaçlandı̆̆ 1 için araştırmada betimleyici nitel araştırma deseni kullanılmıştır. 
Çalışmaya başlamadan önce araştırmanın gerçekleştirildiği il Milli Eğitim Müdürlüğünden bağımsız anaokullarında eğitim gören 5 yaşındaki çocuklar ve çocukların öğretmenleriyle araştırma yapabilmek için gerekli resmi izinler alınmıştır. Çalışma küçük çocuklarla yürütüleceği için ayrıca Yüzüncü Yıl Üniversitesi Etik Kurulundan da izin alınmıştır. Van ilinde bulunan bağımsız anaokullarından düşük sosyoekonomik statüye sahip olan ailelerin çocuklarının devam ettiği bir okulda eğitim gören ve çalışmaya katılmak istediğini belirten beş yaşındaki 24 kız ve 26 oğlan çocuğu katılmıştır. Çocuklarla yapılan görüşmeler başlamadan, her çocuğa istedikleri anda görüşmeyi bırakabilecekleri bilgisi verilmiştir. Ayrıca, görüşmeler süresince çocukların beden dilleri gözlemlenmiş, çocukların sıkıldıkları ya da cevaplamak istemedikleri düşünüldüğünde çocuklara "sınıfına gitmek ister misin?”, ya da “ “başka bir soruya geçmek ister misin?” gibi sorular sorularak, görüşmeyi kontrol edebileceği mesajı verilmiştir. Çocukların isimlerini gizli tutabilmek için onlara takma isimler verilmiştir.

\section{Verilerin Toplanması}

Çalışmanın verileri çocuklarla gerçekleştirilen yarı-yapılandırılmış görüşmeler yolu ile elde edilmiştir. Görüşme formu, cinsiyetçi kalıp yargılar ile ilgili literatür taraması sonucunda oluşturulmuştur(Adler, Kless, \& Adler, 1992; Eagly \& Steffen,1984; Sayılan, 2012; YağanGüder, Güler-Yıldız, 2016; Yılmaz, 2007). Görüşme formunun geçerliliğini arttırabilmek adına, uzman görüşü yöntemi kullanılmış (Yıldırım \& Şimşek, 2005), hazırlanan görüşme formu okul öncesi eğitim de cinsiyet üzerine çalışan iki farklı öğretim üyesinin değerlendirmesine sunulmuştur. Ardından, bir okul öncesi öğretmeni soruları tekrar incelemiş ve görüşme protokollerinin hem anlaşılırlık hem de uygunluk açısından uygulanabilir olduğunu belirtmiştir.

Çalışma kapsamında tüm görüşmeler çocukların okullarında gerçekleştirilmiştir. Bütün görüşmeler ses kayıt cihazı ile kayıt altına alınmış aynı zamanda görüşmeler boyunca araştırmacı tarafından gerekli görülen durumlar ya da diyaloglar not edilmiştir. Çocuklarla yapılan görüşmeler ortalama olarak 10-15 dakika sürmüştür. Çocuklara aşağıdaki yönerge ve sorular yöneltilmiştir:

"Merhaba sana sormak istediğim dört sorum var. Sorulara cevap vermeyi istemezsen bana "buna cevap vermeyeceğim” demen yeterli. İstediğin an kalkıp gidebilirsin. Birazdan sana 
soracağım soruların doğru ya da yanlış cevabı yok. Ben sadece senin düşüncelerini öğrenmek istiyorum. Biliyorsun, dünyada kadın ve erkek olmak üzere iki cinsiyet var, bu durum çocuklar için de aynı. Çocuklar da kız ve oğlan olmak üzere ikiye ayrılırlar. Mesela sen kız çocuğu musun/Oğlan çocuğu musun?

1.Peki kız/oğlan olmanın en sevdiğin tarafları nelerdir?

2.Peki kız/oğlan olmanın sevmediğin tarafları var mı? Neler?

3.Sen çalışmaya başladığın zaman hangi mesleği yapmak istiyorsun?

4. Neden bu mesleği yapmak istiyorsun?

Teşekkür ederim.

\section{Veri Analizi}

Bütün nitel araştırmalarda olduğu gibi bu çalışmada da veri analizine başlamadan önce ilk olarak görüşmeler sırasında alınan ses kayıtları ve tutulan notlar temize çekilmiş ve organize edilmiştir. Verileri analiz etmek için içerik analizi kullanılmıştır. Elde edilen ham verileri daha anlaşılır hiyerarşik bir yapıda kategori setlerine dönüştürmek için veri analizinde açık kodlama kullanılmıştır. Görüşmelerin içinde dağınık bir şekilde bulunan anlam bütünlüğünü ortaya çıkarmak için kelimesi kelimesine detaylı bir analiz yapılmıştır (Strauss \& Corbin, 1990). Öncelikle, görüşme notlarının temize çekilmiş hali her iki araştırmacı tarafından baştan sona okunmuş ardından cinsiyet ile ilgili yapılan herhangi bir anahtar kelime ya da deyimin altı çizilmiş ve kenar notları düşülmüştür. Görüşme notları okunurken bu ortaya çıkan kodlar olabildiğince kısıtlanmaya çalışılmıştır. İlk kodlar belirlendikten sonra bütün veriler baştan kodlanmış ve mevcut koda uymayan verilerle karşılaşıldığında yeni kodlar eklenmiştir. Tüm veriler kodlandıktan sonra araştırmacılar belirli bir kod içindeki tüm verileri incelemiş ve bu süreçte bazı kodları birleştirmişler ya da alt kategorilere ayırmışlardır. En sonunda bütün kodlar kategoriler ve temalar altında toplanmıştır (Hsieh \& Shannon, 2005). Kodlama işleminin detayları Tablo 1'de sunulmuştur.

Tablo 1. Kodlama Kategori ve Temaları

\begin{tabular}{lll}
\hline Temalar/ & Kategoriler & Kodlar \\
Cinsiyetin iyi yanları & & \\
\hline Dış görünüş & Giyim Kuşam & Etek giymek \\
& & Elbise giymek \\
\hline
\end{tabular}




\begin{tabular}{lll}
\hline & Saç & $\begin{array}{l}\text { Uzun saçlı olmak } \\
\text { Renkli toka takmak } \\
\text { Kisa saçlı olmak }\end{array}$ \\
\hline Kişilik özellikleri & Güçlü olmak & $\begin{array}{l}\text { İs yapmak } \\
\text { Koruyup kollamak }\end{array}$ \\
\cline { 2 - 3 } & Uslu olmak & $\begin{array}{l}\text { Kavga etmemek } \\
\text { Anneye yardım etmek } \\
\text { Anne-babayı sevmek/sevilmek }\end{array}$ \\
\hline Beceriler & Ev işleri-Temizlik & $\begin{array}{l}\text { Anneye yardım etmek } \\
\text { Araba sürmek/Para kazanmak }\end{array}$ \\
\hline Çalışmak & Futbol/Top oyunları \\
\hline Oyunlar & Aktif oyunlar & Evcilik \\
\cline { 2 - 3 } & Sembolik oyunlar & Oyun oynatmak \\
& & $\begin{array}{l}\text { Herkesi iyileştirmek } \\
\text { Para kazanmak } \\
\text { Top oynamak }\end{array}$ \\
& Öğretmen & Silah kullanmak \\
\hline
\end{tabular}

Çalışmada güvenirliği sağlamak için çocuklarla yapılan bütün görüşmeler iki araştırmacı tarafından da kodlanmıştır. Araştırmacılar kodları oluşturduktan sonra bütün görüşmeleri ayrı ayrı kodlamış ve kodlarını karşılaştırmışlardır. Çalışmada kodlayıcılar arası güvenirlik. 96 çıkmıştır. Faklı çıkan kodlar üzerinde tartışılmış ve iki araştırmacı bütün kodlamalarda fikir birliğine varmıştır. Kodlayıcılar arası güvenirlik aşağıdaki formülle hesaplanmıştır:

Kodlamanın güvenirliği: $\quad$ Kodlama sayıs1

$$
\text { Toplam kodlanan kısım }
$$

Oluşturulan temalara dayanarak veriler anlamlı bir bütün halinde hikayeleştirilip aktarılmıştır. Çalışmanın katılımcılarını beş yaş grubu çocukların oluşturması, çalışmanın güvenirliğini arttırmak adına katılımcı teyidi gibi yöntemlerin kullanılmasını engellemiştir. Ancak, görüşmeler boyunca çocukların söylemleri sıklıkla özetlenmiş ve çocuklara “.... Söylediğini anladım, doğru anlamış mıyım?” şeklinde sorular yöneltilmiştir. Buna ek olarak, güvenirliği 
arttırabilmek adına detaylı anlatım (thick description) tekniği kullanılmış, oluşturulan kategori ve temalar onları en iyi temsil eden ifadelerden örneklerle açıklanmıştır.

\section{Bulgular}

\section{Çocukların Kendi Cinsiyetlerine Yönelik Cinsiyetçi Kalıp Yargıları Dış Görünüş}

Kendi cinsiyetinin en sevdiği yönü sorulduğunda kız çocuklarının çoğu dış görünüşlerinden bahsetmişlerdir. Oğlan çocuklarından sadece iki tanesi kendi cinsiyetinin en sevdiği yönünü dış görünüşü ile ilişkilendirirken; kız çocuklarından üç tanesi kız olmanın en iyi tarafının etek ve elbise giymek, beş tanesi de uzun saçlı olmak olduğunu ifade etmişlerdir. Aşağıda çocukların verdiği ifadelerden örnekler sunulmuştur.

“Kızlar güzel kıyafetler giyer. Benim sarı elbisem var çok güzel. Güzel klyafetler giymeyi seviyorum en çok.” (Şermin).

“Erkekler yakışıklı olduğu için erkek olmayı seviyorum.” (Murat).

\section{Beceriler}

Kız ve oğlan çocuklarının kendi cinsiyetlerine atfettikleri beceriler incelendiğinde, kız çocuklarının kendilerine daha pasif olan temizlik, anneye yardım etmek, bulaşık yıkamak gibi becerileri yakıştırdığı, oğlan çocukların ise daha aktif olan araba sürmek, kızları kurtarmak, çalışmak gibi becerilere vurgu yaptığı gözlemlenmiştir.

Çalışmaya katılan kız çocuklarından dokuz tanesi kız olmanın iyi tarafının ev işleri ve annelerine yardım etmek gibi işleri yerine getirmek olduğunu belirtmiştir. Çalışmaya katılan oğlan çocuklarından on dört tanesi sahip oldukları cinsiyetin iyi yanını araba sürmek, çalışıp para kazanmak ve alışverişe gidip evin ihtiyaçlarını almak gibi etkinliklerle ilişkilendirmiştir. Çocukların verdikleri cevaplara örnekler şu şekildedir: "Anneme yardım etmeyi çok seviyorum. Bulaşıkları yıkıyorum sehpanın üstüne çıkıp. Annem ekmek yaparken hamur yoğurmasına yardım ediyorum.” (Ayşe). "Araba, uçak sürmek. Erkekler araba sürer. Çarşıya giderler." (Ahmet)

\section{Kişilik Özellikleri}


Çalışmaya katılan kız çocuklarından üç tanesi cinsiyetlerinin en sevdikleri yanının daha sakin olmaları olduğunu belirten ifadeler kullanmışlardır. Bunun yanında dört oğlan çocuğu ise cinsiyetlerinin en sevdikleri yanının güçlü olmak olduğunu belirtmişlerdir. Çocukların ifadelerini örneklendirmek gerekirse: “Anne babaları onları [kızları] çok sever çünkü kızlar kavga etmezler." (Meryem)

"Erkek olmanın en iyi tarafı güçlü olmak. Erkekler babalarına iş yaparken yardım ederler.

Ben boyaları kazıdım. Babama yardım ettim.” (Hasan)

\section{Oyunlar}

Çalışmaya katılan kız çocuklarından üç tanesi kendi cinsiyetlerinin en iyi yanını sek sek ve evcilik oynayabilmek olarak tanımlarken beş tane oğlan çocuğu erkek olmanın en iyi tarafının aktif oyunlar oynayabilmek olduğunu belirtmiştir. Aşağıda çocukların oyunla ilgili ifadelerine yer verilmiştir:

"Bütün arkadaşlarım kız. O yüzden kız olmayı seviyorum ben de. Oyuncak oynuyoruz onlarla." (Gülcan)

"Erkek olmanın en iyi yanı oyun oynamak. Tehlikeli şeyler yapmak." (Mehmet) Çalışmaya katılan çocuklardan biri, erkek olmanın en iyi yanının erkek torun olmak olduğunu belirtmiştir. Tablo 2 çocukların cinsiyetlerinin en iyi yanını tanımlarken kullandıkları kavramları göstermektedir.

Tablo 2. Çocukların Sahip Oldukları Cinsiyetin En İyi Tarafını Tanımlaması

\begin{tabular}{llll}
\hline Temalar & İyi yanı & Kız & Oğlan \\
\hline \multirow{2}{*}{ Dış görünüş } & Güzellik/Yakışıklılık & - & 1 \\
\cline { 2 - 4 } & Saç & 5 & 1 \\
\cline { 2 - 4 } & Giyim Kuşam & 3 & \\
\hline \multirow{2}{*}{ Beceriler } & Aktif/(Araba sürmek, çalışmak) & 1 & 14 \\
\cline { 2 - 4 } & Pasif/(Bulaşık yıkamak, temizlik yapmak) & 9 & - \\
\hline Kişilik özellikleri & Uslu-Sakin/İtaatkar & 3 & - \\
\cline { 2 - 4 } & Güçlü & - & 4 \\
\hline Oyunlar & Edilgen/ Grup oyunları & 3 & - \\
\cline { 2 - 4 } & Hareketli/maceracı & - & 5 \\
\hline Toplam & & 24 & 25 \\
\hline
\end{tabular}




\section{Meslek seçimi}

Kız ve oğlan çocuklarının gelecekte yapmayı istedikleri meslekler incelendiğinde kız çocuklarının öğretmenlik mesleğini; oğlan çocuklarının ise polislik ve askerlik mesleklerini tercih ettikleri gözlemlenmiştir. Tablo 3 ve Tablo 4'da çocukların seçtikleri mesleklerin detayları görülmektedir.

Kız çocukları tarafından tercih edilen dört meslekten en popüler olarak karşımıza çıkan öğretmenlik mesleğidir. 24 kız çocuktan 10 tanesi öğretmen olmak istediğini beyan etmiştir. Öğretmenliği takip eden meslek, doktorluk. 8 k1z çocuğu büyüdüğünde doktor olmak istediğini beyan etmiştir. Annelik bir meslek olmamasına rağmen ilginnçbir şekilde dört katılımcı anneliği meslek olarak belirtmiştir. 1 kız çocuğu hemşire, 1 kız çocuğu ise inşaatçı olmak istediğini beyan etmiştir. Çocukların bu meslekleri seçme nedenleri incelendiğinde nedenlerin iki temel kategoride toplandığı dikkat çekmektedir (1) bireysel çıkar (BÇ), (2) ailevi/ toplumsal çıkar (ATÇ). Bireysel çıkarlar kategorisinde, mesleği seçme nedeni sadece keyfi sebeplere bağlanmıştır; örneğin öğretmenlik mesleğini seçme nedeni bireysel çıkar kategorisine giren bir katılımc1, bu mesleği kendisi okulu sevdiği için seçmek istediğini belirtmiştir. Yine öğretmenlik mesleğinde ailevi/toplumsal çıkar kategorisinde kodlanan bir neden ise başkalarının çıkarını gözetmektedir, örneğin; çocuklara oyun oynatmak için ya da ders vermek için. Tablo 3'te nedenlerin yanında kodlandığı kategorinin isimlerinin kısaltmaları sunulmuştur. Kız çocuklarının mesleği seçme nedenlerinin 21 tanesi Ailevi/toplumsal çıkar kategorisinde iken, yalnızca 3 tanesinin bireysel çıkar kategorisinde olduğu saptanmıştır.

Tablo 3. Kız Çocuklarının Seçtikleri Meslekler ve Nedenleri

\begin{tabular}{|c|c|c|c|}
\hline Meslek & Seçme nedeni & $\begin{array}{l}\text { Bireysel- } \\
\text { Ailevi/Toplumsal } \\
\text { Clıar }\end{array}$ & Frekans \\
\hline \multirow[t]{3}{*}{ Öğretmen } & Ders vermek için & ATÇ & 6 \\
\hline & Çocuklara oyun oynatmak için & ATÇ & 2 \\
\hline & Okulu sevdiği için & $\mathrm{BÇ}$ & 2 \\
\hline \multirow[t]{3}{*}{ Doktor } & İnsanları iyileştirmek için & ATÇ & 5 \\
\hline & Serum/İğne yapmak için & ATÇ & 2 \\
\hline & Çok para kazanmak için & $\mathrm{BC}$ & 1 \\
\hline
\end{tabular}




\begin{tabular}{llll}
\hline \multirow{2}{*}{ Anne } & Çocuklara bakmak & ATÇ & 3 \\
\cline { 2 - 4 } & Evi işi yapmak & ATÇ & 1 \\
\hline Hemşire & İğne yapmak için & ATÇ & 1 \\
\hline İnşaatçı & Bize ev yapmak için (evleri yok) & ATÇ & 1 \\
\hline Toplam & & & 24 \\
\hline
\end{tabular}

Oğlan çocuklarından bir tanesi meslek olarak ele alınamayacak bir seçim yaptığı için o çocuğa ait veri analiz dışı bırakılmıştır. Analize dahil edilen 23 oğlan çocuğun verisi incelendiğinde, oğlan çocuklar tarafindan beyan edilen 9 meslek arasında en popüler olan mesleğin asker/polis olduğu anlaşılmıştır $(n=7)$. Asker/polisliği sırasıyla, şoförlük(n=4), tamircilik $(n=3)$, sporcu $(n=3)$, öğretmen $(n=2)$, pilot $(n=3)$, çoban $(n=1)$, firıncı $(n=1)$ ve memur $(\mathrm{n}=1)$ takip etmiştir. Kız çocuklarının aksine oğlan çocuklarının meslek seçimlerinin nedenlerinin daha çok bireysel tercihe dayandığı gözlemlenmiştir. Yalnızca 6 oğlan çocuğu, meslek seçimine ilişkin ailevi/toplumsal faydaya dayanan bir neden sunmuşken, geriye kalan 21 kodlanan cevap bireysel çıkara dayanan bir neden içermektedir.

Tablo 4. Oğlan Çocuklarının Seçtikleri Meslekler ve Nedenleri

\begin{tabular}{llcc}
\hline Meslek & Seçme nedeni & $\begin{array}{l}\text { Bireysel- } \\
\text { Ailevi/ } \\
\text { Topumsal } \\
\text { Çıar }\end{array}$ & Frekans \\
& & BÇ & 3 \\
\hline \multirow{2}{*}{ Asker/polis } & Polis arabasına binip sürmek için & ATÇ & 2 \\
\cline { 2 - 4 } & Suçluları yakalamak için & BÇ & 2 \\
\cline { 2 - 4 } & Her yere ateş etmek/insanları öldürmek için & BÇ & 2 \\
\hline \multirow{2}{*}{ Şoför } & Yolcu alıp para kazanmak için & BÇ & 2 \\
\cline { 2 - 4 } & Arabaları çok sevdiği için & BÇ & 3 \\
\hline Tamirci & Arabaları çok sevdiği için arabaları tamir etmek için & BÇ & 3 \\
\hline Sporcu & Top oynamak. Maç yapmak için & ATÇ & 2 \\
\hline Öğretmen & Öğrencileri olması onlara bir şeyler öğretmek için & BÇ & 3 \\
\hline Pilot/kaptan & Havada uçmak için & ATÇ & 1 \\
\hline Çoban & Keçiler bize süt ve yoğurt verdiği için & ATÇ & 1 \\
\hline Firıncı & Kardeşi büyüsün diye ekmek yapmak için & - & 1 \\
\hline Memur & Babası memur olduğu için & & 25 \\
\hline Toplam & & & \\
\hline
\end{tabular}




\section{Tartışma ve Sonuç}

Türkiye'de kadınlar çok dirençli ve süreklilik arz eden ekonomik, kültürel, ve yapısal ayrımcılığa maruz kalmaktadırlar. Kadınların uğradıkları bu haksızlığı önlemenin yolu da kendi çabaları ile gerçekleşebilir (Cin \& Walker, 2013). Feminist pedagojinin uygulama alanının olması ve yaygınlaştırılması, toplumda eşitsizliğe bağlı sorunların çözüm yollarından biri olabilir. Çünkü feminist pedagoji, toplumsal bir değişimi öngörür ve bu değişim doğrultusunda bireyler, eleştirel düşünme becerilerini başkalarına saygı duyma ve başkalarıyla birlikte çalışabilme becerileriyle bütünleştirirler. Feminist pedagoji, öğrenci ve öğretmenin yeni düşünme biçimlerini, özellikle bireyin bütünlüğü ve tamlığı ile, başkalarıyla ilişkilerini geliştirme yollarını öğrenmelerine yardımcı olma çabasındadır. Cin ve Walker (2013) Türkiye'de öğretmenlik yapan ve 3 ayrı nesli temsil eden 15 öğretmenle gerçekleştirdikleri çalışmalarında 1920 ile 1960 yıllarında doğan öğretmenlerin çok daha fazla cinsiyete yönelik ayrımcılık kurbanı olduklarını gözlemlemişlerdir. 1970-1980 yılları arasında doğan ve yine öğretmenlik yapan neslin ise daha fazla özgürlüğe ve yaşam standartlarını artırma şansına sahip olduklarını belirtmişlerdir. Bu çalışmanın sonuçları toplumda kabul ve saygı gören öğretmenlik mesleğini icra eden kadınların dahi ayrımcılığga maruz kaldıklarını ortaya koyması açısından son derece düşündürücüdür. Türkiye'de halen kızlar ve oğlanların eşit eğitim olanaklarına sahip olması tamamen sağlanamamıştır. Özellikle doğu bölgelerinde ekonomik, kültürel ve etnik nedenlerle daha da vahim bir tablo karşımıza çıkmaktadır (Şahin \& Gülmez, 2000). Türkiye'de eğitimde cinsiyet eşitliği kavramı halen kızların ve oğlanların tamamının eğitim alması ile ölçülmektedir. Cinsiyet eşitliğinden bahsederken sayılara odaklanmak yerine daha etkili ve anlamlı bir içerikten söz edilmesi ve bütün çocuklara eşit şekilde davranıldığı ve eşit firsatların sunulduğu ortamın oluşturulması garanti altına alınmalıdır (Subrahmanian, 2005). Sağlam dayanaklar üzerine kurulmuş bir cinsiyet eşitliği anlayışı, eğitimdeki koşulları, müfredatın ve ders kitaplarının neden olduğu cinsiyetçi kalıp yargıları, eğitim hayatı ve iş hayatı arasındaki cinsiyet eşitsizliklerini konu edinir ve eğitimin -eğitim yoluyla da tüm yaşantının- bu eşitsizlikleri yaratan düşünceden bağımsızlaştırılmasını öncelik olarak belirler.

Her kültürde sosyal normlarla şekillenen toplumsal cinsiyet rolleri mevcuttur ve bu cinsiyet kimlikleri çerçevesinde erkeğin ve kadının nasıl görüneceği, davranacağı ve birbirleri 
ile olan ilişkileri şekillenir. Cinsiyete ilişkin sterotipler çok erken yaşlarda oluşmaya başlar. Powlishta, Sen, Serbin, Poulin-Dubois, \& Eichstedt (2001) 5 yaş grubundaki çocukların sıfatlar ve özelliklere ilişkin cinsiyet sterotiplerine sahip olduğunu belirtmektedir. Miller, Lurye, Zosuls, \& Ruble (2009) yaptıkları çalışmada, kız ve oğlan olmanın ne anlama geldiği sorulduğunda kız olmanın daha çok dış görünüşe, fiziksel özelliklere dayanarak açıklandığını (kıyafet, makyaj, saç, parfüm), ve oğlan olmanın ise daha çok etkinlik ve davranış temelli açıklandığını (vurmak, boğuşma oyunları, aksiyon oyunları vb.) ortaya koymuştur. Benzer bir durum, mevcut çalışmaya katılan çocukların cevaplarında da gözlemlenmiştir. "Kız olmanın en çok nesini seviyorsun?” sorusuna kız çocukları fiziksel özelliklerine, kılık kıyafetlerine odaklanarak cevap vermiştir. $\mathrm{Bu}$ aslında kendi cinsiyetlerini nasıl tanımladıklarını göstermektedir. Dış görünüş (özellikle saç ve giyim kuşam) 8 kız çocuk tarafından kız olmanın en iyi tarafını açıklamak için kullanılırken, sadece iki oğlan çocuğu tarafından kullanılmıştır. Oğlan çocuklarının ise yarıdan fazlası $(n=14)$, oğlan olmanın en çok sevdikleri yönünü becerilerine odaklanarak açıklamışlardır. İlginç bir şekilde, mevcut çalışmada kız olmanın en iyi tarafı açıklanırken daha çok becerilere odaklanılmıştır. Diğer bir deyişle, kız olmanın en güzel tarafını dış görünüş temelli açıklayan kız katılımcı sayısı sekiz iken; kız olmanın en güzel tarafını beceriler temelli açıklayan kız sayısı ise ondur. Ancak, burada dikkat çeken bir nokta kızlar tarafından öne sürülen becerilerin daha çok geleneksel cinsiyet rollerine uygun olmasıdır. Yani, kız olmanın en güzel tarafını açıklarken becerileri kullanan on kız çocuğundan 9 tanesi bulaşık yıkamak, temizlik yapmak gibi geleneksel toplumsal cinsiyet rollerinin benimsendiği bir ailede kadının rolü olarak algılanan becerilere odaklanırken yalnızca bir kız çocuğu maskülen olarak algılanan becerilere (araba sürmek, çalışmak) odaklanmıştır. Cristofaro ve Tamis-LeMonda (2008), anne ve babaların kız ve oğlan çocuklarıyla yaptıkları konuşmaları incelediklerinde, kız çocuklarıyla konuşan anne ve babaların daha çok fiziksel görünüşe, oğlan çocuklarıyla konuşan anne babaların ise daha çok davranışa odaklandığını ortaya koymuştur. Bu bağlamda değerlendirildiğinde, mevcut çalışmada ortaya çıkan bu ilginç durumun, çocukların yaşadığı kültürden etkilendiği çıkarımı yapılabilir. . Çalışmaya katılan çocuklar hem oldukça muhafazakâr hem de düşük sosyo-ekonomik düzeyde ailelerden gelen çocuklardır. Ataerkil yapının daha baskın olduğu bu gibi sosyal yapılarda, kadın ev içerisinde sahip olduğu rollerle daha çok tanımlanmakta ve kadın olmak bu rollerle daha çok 
özdeşleşmeye başlamaktadır (Bingöl, 2014). Ayrıca, ailenin sosyo-ekonomik durumu kötüleştikçe çocuklarının eğitim alma şansının azalması bütün dünyada gözlemlenen bir durumdur (Tansel, 2002). Özellikle bu çalışmanın gerçekleştiği Doğu Anadolu illerinde, ailelerin geçim kaynaklarının tarım ve hayvancılık olduğu göz önüne alınırsa çocuklar ailelerine yardım için tarımda çalışmak zorunda kalmaktadırlar (Alat \& Alat, 2011). Sosyoekonomik durumu düşük olan aileler kız ve oğlan çocuklarının eş zamanlı olarak eğitim almasını sağlayamadıklarında ve birinden vazgeçmek durumunda kaldıklarında ve bu genelde kız çocukları olmaktadır (Smits \& Gunduz-Hosgor, 2006). Okulu bırakmak zorunda kalan kız çocuklarının önünde ev işlerine yardım etmek ve kardeşlerinin bakımını üstlenmekten başka bir yaşam kurma imkânı görünmemektedir (Cin \& Walker, 2016). Bu nedenle, çalışmanın gerçekleştirildiği bu dezavantajlı grubun aile yaşantısında da, ev içinde kadın olmaya ilişkin fiziksel özellikler yerine kadının ev içindeki rolü ve ev içerisinde yaptığı işler kadınlıkla daha fazla ilişkilendiriliyor olabilir. $\mathrm{Bu}$ durum da, özellikle kız çocuklarının cinsiyetlerini tanımlarken ev işlerine odaklanmalarıyla sonuçlanmış olabilir.

Alan yazınında cinsiyet sterotiplerini inceleyen bazı çalışmalar, özellikle oğlan çocukların, erkekleri tamımlarken cesur, güçlü gibi ifadeler kullandıklarını ortaya koymuştur (Sani \& Bennett, 2001; Sani, Bennett, Mullally, \& MacPherson, 2003). Bu çalışmalarla paralel olarak, mevcut çalışmada da kızların en sevdikleri yönü açıklarken, büyüklerin sözünü dinleme, uslu olma gibi özellikleri kullandıkları görülürken, erkeklerin güçlü olmak gibi özellikleri kullandıkları gözlemlenmiştir.

Yapılan birçok çalışma, medyanın cinsiyet stereotipilerini şekillendiren güçlü bir araç olduğunu göstermektedir (Ersoy-Çak, 2010; Halim \& Ruble, 2010). Medyada kadın ve erkeğin nasıl yansıtılacağı toplumda yaygın kabul gören cinsiyet kimlikleri tarafından belirlenir. Araştırmaların çok net gösterdiği bir gerçek, medya araçlarının geleneksel toplumsal cinsiyet rollerini desteklediği yönündedir (Ersoy-Çak, 2010; Ruble, Martin, \& Berrenbaum, 2006). Bu nedenle medyada yayınlanan reklamlarda kadın genellikle uzun saçlı, etek-elbise giyen, temizlik ve yemek işleri ile uğraşan ve kadınlara özgü olduğu kabul edilen meslekleri icra ederken yansitılır (Yılmaz, 2007). Bu görüşe paralel olarak bu çalışmanın bulguları daha önceki çalışmalarla benzerlik göstermektedir. Read'in (2011) çalışmasında olduğu gibi kız çocukları sosyokültürel olarak kadınların güzel ve fiziksel olarak çekici olmasının topluma 
empoze edilmesinin sonucu olarak cinsiyetleri ile ilgili sevdikleri yönün diş görünüşle alakalı olduğuna dair cevaplar vermişlerdir. Dış görünüş genellikle giyim kuşam, saç ve süslenme olarak karşımıza çıkmaktadır. Feminizm düşüncesinin oluşumunda etkili olan isimlerden biri Wallstonecraft 1792 yayınladığı "Kadın Haklarının Savunulması" isimli kitabında, biyolojik cinsiyet açısından kadın ve erkek arasında hiçbir fark olmamasına karşın, toplumsal yaşamda cinsiyet eşitsizliğine sebep olan ataerkil yapının temelinin eğitimdeki fırsat eşitsizliği olduğuna vurgu yapmıştır (akt. Ersoy Çak, 2010). Ardından eğitimde fırsat eşitliği feminizmin önemli konulardan biri haline gelmiştir. Feminist pedagoji, Feminist teoriyi öğretme ve öğrenme süreçleriyle birleştiren bir yaklaşımdır. Feminist pedagoji öncelikle eğitimin ne olabileceğine yönelik bir bakış açısını yansıtıyor gibi gözükse de, aslında çoğunlukla eğitimin ne olmadığına ilişkin bir vizyon ile başlar. Öğretmen-öğrenci ve öğrenci-öğretmen ilişkisine nesneler değil, özneler olarak davrandığımızı savunan bu yaklaşımın vizyonu, bireylere özgürleştirici bir eğitim ortamı sunar. Feminist pedagojinin sağladığı özgürlük ile; cinsiyetçilik, ırkçılık, sınıfçılık gibi yıkıcı ayrımlardan kurtularak, farklılıklarla uyum içinde var olmayı öğrenebiliriz. Böyle bir ortamda öğrenen bireyler farklılıklardan korkmak yerine, farklılıklara saygı duyacaklar ve kendileri kadar başkalarının öğrenmesini de önemseyeceklerdir (Esen, 2019). Günümüzde okullar toplumsal cinsiyet ayrımını ortadan kaldıramadıkları gibi yeni cinsiyetçi kalıp yargıların oluşmasını da engelleyememektedir. Ne yazık ki okullar hem sunulan bilgi süreçleri aracılığıyla hem de okulun sahip olduğu kültürel iklim vasıtasıyla cinsiyetçi kalıp yargıların oluşmasında önemli bir rol oynamaktadır. Özellikle ders kitaplarının cinsiyetçi kalıp yargıların oluşması, yaygınlaşması ve pekişmesinde rol oynadığı ortaya çıkmıştır (Esen \& Bağl1, 2002). Erkekler cesaret, zeka ve başarı eylemleri içinde bulunurken kadınlara biçilen rol genellikle itaat, fedakarlık ve bağımlılık gibi eylemleri içermektedir. Ders kitaplarında kadın erkek ilişkisinde güçlü olan yan daima erkek olarak karşımıza çıkmaktadır. Bütün güç öğelerinin erkeğe yüklendiği bir ortamda kadın için oluşan imge zayıf, güçsüz, pasif, duygusal ve korunmaya muhtaç gibi özelliklerle betimlenmektedir. Bu olumsuz kalıp yargılar kadının hem benlik algısını dolayısıyla da kendine verdiği değeri şekillendirmektedir. Kadınların çocukluklarından itibaren oluşturdukları bu imgeler ilerde nasıl bir yaşam süreceklerini belirlemektedir; çünkü, kadınların neyi başarabileceklerine dair kararları bu imgelerden etkilenmektedir (Esen \& Bağlı, 2002). Bu çalışmada da durum farklı olmamış yine kız 
çocukları kendilerine toplumda etki gücü düşük bulaşık yıkamak gibi görevleri seçerken oğlan çocukları araba kullanmak gibi aktif rolleri benimsemişlerdir. Ne yazık ki, öğretmenler çoğunlukla cinsiyetçi kalıp yargıların oluşmasını destekleyecek şekilde kız ve oğlan çocuklarına farklı biçimde davranmaktadırlar (Tan, 2008). Oysa Erden (2009) okul öncesi öğretmen adaylarının cinsiyet eşitliği üzerine ders aldıklarında cinsiyetçi tutumlarının ve kalıp yargılarının önemli ölçüde azaldığını belirtmiştir. Öğretmenlerin toplumsal cinsiyet eşitliğini benimseyip içselleştirmeleri önemlidir çünkü çocuklar küçük yaşlardan itibaren cinsiyetçi kalıp yargıları ailede ve toplumda edinerek okula gelmektedirler. Küçük yaşlarda edinilen beceri ve deneyimlerin uzun ömürlü olduğu göz önüne alındığında, öğretmenler bu cinsiyetçi tutumların pekişmeden ortadan kalkmasına yardımcı olacakladır (Temiz \& Cin, 2017).

Bu noktada belirtilmesi gereken önemli bir diğer nokta ise okul öncesi eğitim alanının doğal yapısıdır. Okul öncesi eğitim alanı kadın popülasyonun çok yüksek olduğu, erkek öğretmen sayısı ya da baba katılım düzeyinin ise düşük olduğu bir alan olarak karşımıza çıkmaktadır (Ünlü-Çetin, 2016). Okul öncesi eğitimin çocukların bakış açısını değiştirme ya da etkileme gücüne sahip olan önemli bir süreç olduğu düşünüldügünde, bu durumun çok ciddi bir eksiklik olduğu ortaya çıkmaktadır. Chambers ve diğerleri (2018) ilkokul çocuklarının meslek seçimlerini belirleyen en önemli unsurların çocukların anne babaları ve yakın akrabaları olduğunu, düşük sosyo-ekonomik düzeyden gelen çocuklar için ise öğretmenlerin çocukların meslek seçimini etkileyen önemli bir unsur olduğunu vurgulamıştır. Mevcut çalışmada bu sonucu destekler niteliktedir. Düşük sosyo-ekonomik düzeydeki ailelerin çocuklarının katılımcı olduğu bu çalışmada, öğretmenlik mesleğini seçen kız sayısının, öğretmenlik mesleğini seçen oğlan sayısından 5 kat fazla olduğu saptanmıştır. Bu durum, okul öncesi eğitim alanında erkek öğretmen eksikliğinin bir yansıması ve aynı zamanda geleneksel toplumsal cinsiyet rolleri algısını destekleyen bir durumdur.

Toplumda erkeklerin hareketli, bağımsız ve maceracı oyun ve etkinliklere katılmaya kızlardan daha uygun olduklarına dair inanç bulunmaktadır. Fiziksel güç ve hareket isteyen ya da bağımsız yapılabilen kamp yapma, kayığa binme, kılıç kuşanma gibi dış mekânda yapılan işler çizgi filmlerde oğlan karakterler tarafından yapılırken kızlar genellikle evcilik, körebe ve halay çekmek gibi grupla yapılabilen oyunlarda gösterilmektedir (Kalaycı, 2015). Bu durum oğlanların bağımsız ve bireysel hareket etme ve düşünme becerilerini geliştirip kız çocukların 
kendilerinden beklendiği gibi itaatkâr ve pasif olmalarına neden olabilir. Brechet (2013) çocukların resimlerini incelediği çalışmasında oğlan çocuklarının daha öfkeli yüzler çizerken kızların daha duygusal ya da üzgün yüzler çizdiklerini gözlemlemiştir. Brechet'in (2013) iddiasına göre toplum öfkeyi kız çocuklarına daha az yakıştırır aynı şekilde üzüntü ve duygusallığı oğlan çocuklarına daha az yakıştırmaktadır. Toplumun kız ve oğlan çocuklarına yönelik bu beklentisi onların kişilik özelliklerini buna paralel olarak da çizdikleri resimleri etkilemektedir. Mevcut çalışmada bunlara ek olarak hiçbir kategoriye girmeyen fakat kültürün cinsiyetçi tutumlar üzerindeki etkisini göstermesi açısından önemli olan bir cevap da oğlan çocuklardan birinin cinsiyetinin iyi yanını tanımlarken 'erkek torun olmak' cevabını vermesidir. Bu durum halen toplumda oğlan çocuklarının kız çocuklarından daha değerli görüldüğünün ipuçlarını vermektedir. Oğlan çocukları daha değerli görüldüğünden daha fazla özgürlük, eğitim imkânı ve yaşam standartlarına ulaşmaktadırlar(Sarıer, 2010).

Bazı mesleklerin kadınlar bazı mesleklerin de erkekler tarafından yapıldığına dair toplumda yaygın bir kanı vardır. Çocuklardan bir bilim insanı çizmeleri istendiğinde bir erkek figürü çizmeleri bu durumdan kaynaklanmaktadır (Güler \& Akman, 2006). Bu çalışmada da çocukların meslek seçimlerine baktığımızda çocukların mesleklerle ilgili cinsiyetçi kalıp yargılardan etkilenerek kendi cinsiyetlerine uygun olduğunu düşündükleri meslekleri seçtikleri gözlemlenmiştir. Kadınların meslek çeşitlilikleri pek çok ders kitabında öğretmenlik ve hemşirelik olarak karşımıza çıkmaktadır. Bu çalışmaya katılan kız çocuklarının en çok tercih ettikleri meslek de öğretmenlik olmuştur.

Çocuklar için hazırlanan çizgi filmlere baktığımızda da farklı bir durumla karşılaşmamaktayız. Türkiye'de yayınlanan en popüler yerli çizgi filmlerden olan Pepee çizgi filmi incelendiğinde kadın karakterlerin öncelikli sorumlulukları çocuk bakımı ve ev işleri olarak yansıtılmaktadır. Pepee çizgi filmi Türk toplumsal yapısının özelliklerine uygun hazırlandığından toplumsal yaşamdaki kadın ve erkek arasındaki iş bölümünün çizgi filmin içeriğinde karşımıza çıktığını görmekteyiz. Bu iş bölümü içerisinde kadın karakterleri "anne ve eş", erkek karakterleri de "dışarıda çalışan" olarak betimlemek, toplumda var olan cinsiyetçi kalıp yargıların pekişmesine neden olacaktır (Kalaycı, 2015). Bu çalışmanın bulguları da kadın ve erkeğe atfedilen bu iş bölümünden etkilenmiş görünmektedir. Çocuklar gelecekteki meslek seçimleriyle ilgili olarak toplumda ve medyada gördükleri örneklerden etkilendiklerinden kız 
çocukları öğretmen ya da anne olmayı seçerken erkekler asker polis şoför gibi mesleklere yöneleceklerinin işaretini vermişlerdir.

Ailelerin cinsiyet tutumlarının çocuklarının cinsiyet tutumlarını etkilediği bilinen bir gerçektir. Aileler ne kadar eşitlikçi tutuma sahipse çocukları da cinsiyetçi kalıp yargıları o kadar az geliştirirler (Fagot \& Leinbach, 1995). Buradan hareketle okul öncesi eğitimde de cinsiyet açısından eşitlikçi bir tutum benimsenirse çocukların cinsiyetçi kalıp yargılar edinmelerinin önüne geçilebilir. Fakat cinsiyet ile ilgili çeşitli mitler bulunmaktadır ve bu mitler cinsiyet eşitliğini sağlamanın önünde engel teşkil ettiği gibi cinsiyetçi kalıp yargıların pekişmesinde de rol oynamaktadır. Bu mitler şu şekilde sıralanabilir: Okul öncesi eğitimde

cinsiyet tartışılması gereken bir durum değildir, küçük çocuklar cinsiyeti bilmezler ve önemsemezler, cinsiyet eşitliği eğitiminde ailenin desteğine gerek yoktur, cinsiyetçi tutumlar ve kültür birbirinden çok etkilenmezler (MacNaughton, 2000). Öğretmenlerin cinsiyetçi kalıp yargılarla mücadele etmek için kullanabilecekleri stratejiler son derece sınırlıdır.

Çocuklara cinsiyet eşitliğini öğretmek çok karmaşık ve zordur. Cinsiyet eşitliği algısının sadece çocuklara cinsiyetçi olmayan davranışlarla model olmak ve onların kalıp yargılardan

uzak bir şekilde oyun oynamasını sağlamakla oluşturulması oldukça zordur. . Bunların yanında şu stratejilerde kullanılmalıdır; çocuklar arasında cinsiyetçiliği durdurmak, aileleri cinsiyetçi tutumlar hakkında bilgilendirmek, çocukların konuşmalarından cinsiyetçi söylemleri çıkarmak, çocukların kendi cinsiyetlerindeki iyi tarafları görmelerini sağlamak, çocuk hikâyelerindeki cinsiyetçi ifadeleri ortadan kaldırmak (MacNaughton, 2000).

\section{Makalenin Bilimdeki Konumu}

Temel Eğitim/Okul Öncesi Öğretmenliği

\section{Makalenin Bilimdeki Özgünlüğü}

Okul öncesi dönemdeki çocukların cinsiyetlerine ilişkin düşüncelerinin ve meslek seçimlerinin üzerine yapılan bu nitel çalışmayı alan yazındaki diğer çalışmalardan ayıran özelliği küçük çocuklarla yapılmış olmasıdır. Alan yazındaki diğer çalışmalar genellikle öğretmen adayları ile yapılmıştır. Bu çalışma cinsiyetçi kalıp yargılarının ne kadar küçük yaşta ortaya çıktığını gözler önüne sermektedir. Ülkemizde toplumsal cinsiyet eşitliği konusunda kat edilmesi gereken uzun bir mesafe vardır ve okul öncesi eğitim toplumsal cinsiyet eşitliğinin 
sağlanması için çok elverişli ortam sunmaktadır. Erken yaşta kazanılan beceri, tutum ve davranışların kalıcılığı göz önüne alındığında bu çalışma özellikle kız çocukların toplumda hakim olan cinsiyetçi kalıp yargılardan etkilenmemeleri için önlemler alınmasına yardımcı olabilir.

\section{Kaynakça}

Adler, P., S. Kless, and P. Adler. (1992). Socialization to gender roles: Popularity among elementary school boys and girls. Sociology of Education 65, 169-87.

Akerlof, G. A., ve Kranton, R. E. (2000). Economics and identity. The Quarterly Journal of Economics, 115(3), 715-753.

Akın, A., ve Demirel, S. (2003). Toplumsal cinsiyet kavramı ve sağlığa etkileri. Cumhuriyet Üniversitesi Tıp Fakültesi Dergisi Halk Să̆lı̆̆ Özel Eki, 25(4), 73-83.

Aksoy, N. (2006). Toplumsal cinsiyete duyarlı bütçeleme ve kadının statüsü genel müdürlüğ̈̈nün rolü. Kadın statüsü uzmanlığı tezi, T.C. Başbakanlık Kadının Statüsü Genel Müdürlüğü, Ankara.

Alat, Z. ve Alat, K. (2011). A qualitative study of parental resistance to girls'schooling.

Educational Science: Theory Practice, 11, 1369-1373.

Amato, P. R., and Fowler, F. (2002). Parenting practices, child adjustment, and family diversity. Journal of Marriage and Family, 64(3), 703-716.

Bandura, A. (1989). Human agency in social cognitive theory. American Psychologist American Psychological Association, 44(9), 1175-1179.

Blakemore, J. E. O. (2003). Children's beliefs about violating gender norms: Boys shouldn't look like girls, and girls shouldn't act like boys. Sex Roles, 48(9-10), 411-419.

Beşpınar, F. U. (2014). Toplumsal cinsiyet ve aile, Türkiye aile yapısı araştırması tespitler, öneriler, araştırma ve sosyal politika serisi 07, Birinci Basım, 2014, İstanbul ISBN: 978 605-4628-55-1; 234-276.

Bingöl, O. (2014). Toplumsal cinsiyet olgusu ve Türkiye'de kadınlı, KMÜ Sosyal ve Ekonomik $\quad$ Araştırmalar Dergisi, 16 (Özel Sayı I), 108-114.

Brechet, C. (2013). Children's gender stereotypes through drawings of emotional faces: Doy boys draw angrier faces than girls? Sex Roles, 68, 378-389. 
Breen, R., and Garcia-Penalosa, C. (2002). Bayesian learning and gender segregation. Journal of Labor Economics, 20(4), 899-922.

Chambers, N., Kashefpakdel, E. T., and Rehill, J. (2018). Drawing the future: Exploring the career aspirations of primary school children from around the world. London: Education and Employers.

Cin. F. M., Karlidag-Dennis, E., \& Temiz, Z. (2020). A Capabilities-based Gender Equality Analysis of Educational Policy-Making and Reform in Turkey. Gender and Education, $32(2), 244-261$.

Cin, F. M., and Walker, M. (2013). Context and history: Using a capabilities-based social justice perspective to explore three generations of western Turkish female teachers' lives. International Journal of Educational Development, 33(4), 394-404.

Cin, F. M., and Walker, M. (2016). Reconsidering girls' education in Turkey from a capabilities and feminist perspective. International Journal of Educational Development, 49, 134143.

Cristofaro, T. N., and Tamis-LeMonda, C. S. (2008). Lessons in mother-child and father-child personal narratives in Latino families. In A. McCabe, A. Bailey, and G. Melzi (Eds.), Spanish-language narration and literacy: Culture, cognition, and emotion (pp. 54-91) Cambridge: Cambridge University Press.

Cunningham, M. (2001). The influence of parental attitudes and behaviors on children's attitudes toward gender and household labor in early adulthood. Journal of Marriage and Family, 63(1), 111-122.

Dökmen, Z. (2014). Toplumsal cinsiyet, sosyal psikolojik açıklamalar. İstanbul: Remzi Kitapevi.

Eagly, A. H., and Steffen, V. J. (1984). Gender stereotypes stem from the distribution of women and men into social roles. Journal of personality and social psychology, 46(4), 735754.

Ecevit, Y. (2010). Iş̧ǚü piyasasında toplumsal cinsiyet eşitliği el kitabı. British Council,Türkiye İş Kurumu Genel Müdürlüğü, Çalışma ve Sosyal Güvenlik Bakanlı̆̆ı işbirliğiyle. 
Ecevit, Y. ve Karkıner, N. (2011). Toplumsal cinsiyet sosyolojisi. Anadolu Üniversitesi. Eskişehir: Web Ofset.

Erden, F. T. (2009). A course on gender equity in education: Does it affect gender role attitudes of preservice teachers? Teaching and Teacher Education, 25(3), 409-414.

Ersoy-Çak, Ş. (2010). Toplumsal Cinsiyet ve Feminizm Teorileri Bağlamında Türkiye'deki Reklam Filmleri Ve Popüler Müzik Videoları, Yedi Dokuz Eylül Güzel Sanatlar Fakültesi Dergisi, 4, 101-110.

Esen, Y. (2014). Feminist pedagoji nedir? Eleştirel pedagoji, 31, 17-23.

Esen, Y. (2019). Projections of an emancipatory praxis experience through a feminist pedagogical framework. New Trends and Issues Proceedings on Humanities and Social Sciences, 6(4), 79-86.

Esen, Y., ve Bağlı, M. T. (2002). İlköğretim ders kitaplarındaki kadın ve erkek resimlerine ilişkin bir inceleme. Ankara Üniversitesi Eğitim Bilimleri Fakültesi Dergisi, 35(1-2), 143-154.

Fagot, B.I., and Leinbach, M.D. (1995). Gender knowledge in egalitarian and traditional families. Sex Roles, 32, 513-526.

Fincancıoğlu, N. ve Bulut, A. (2008). Öğretmen ve öğretmen adaylart için cinsel sağllk eğitimi (5. Bask1). İstanbul: Ceren Basımevi.

Ghouri, A. M., and Abrar, N. (2010). Dual earners and balance in their family and work life: findings from Pakistan. European Journal of Social Sciences, 17(1), 28-40.

Gooden, A. M., and Gooden, M. A. (2001). Gender representation in notable children's picture books: 1995-1999. Sex Roles, 45(1-2), 89-101.

Gore, J., Holmes, K., Smith, M., Fray, L., McElduff, P., Weaver, N., and Wallington, C. (2017). Unpacking the career aspirations of Australian school students: towards an evidence base for university equity initiatives in schools. Higher Education Research \& Development, 36(7), 1383-1400.

Güler, T., ve Akman, B. (2006). 6 yaş çocuklarının bilim ve bilim insanı hakkındaki görüşleri. Hacettepe Üniversitesi Eğitim Fakültesi Dergisi, 31(31). 
Halim, M. L., and Ruble, D. (2010). Gender identity and stereotyping in early and middle childhood. In Handbook of gender research in psychology (pp. 495-525). Springer, New York, NY.

Hepşen, Ö. (2010). Tevrat, İncil ve Kuran-ı Kerim'de kadın bedeni. (Yayımlanmamış yüksek lisans tezi). Ankara Üniversitesi, Sosyal Bilimler Enstitüsü, Ankara.

Hsieh, H. F. and Shannon, S. E. (2005). Three approaches to qualitative content analysis. Qualitative Health Research, 15(9), 1277-1288.

Kalan, Ö. G. (2010). Reklamda çocuğun toplumsal cinsiyet teorisi bağlamında konumlandırılışı: 'Kinder' reklam filmleri üzerine bir inceleme. İstanbul Üniversitesi İletişim Fakültesi Dergisi| Istanbul University Faculty of Communication Journal, 1(38), 75-89.

Kalaycı, N. (2015). Toplumsal cinsiyet eşitliği açısından bir çizgi film çözümlemesi: PEPE. Eğitim ve Bilim, 40(177), 243-270.

Kelly, A. (1989). "When I grow up I want to be a...": A longitudinal study of the development of career preferences. British Journal of Guidance and Counselling, 17, 179-200.

Koray, M. (2011). Avrupa Birliği ve Türkiye'de “cinsiyet” eşitliği politikaları: Sol-feminist bir eleştiri, Çalışma ve Toplum Dergisi, 2, 13-54.

MacNaughton, G. (2000). Rethinking gender in early childhood education. Sage Publications, Ltd., London.

Martin, C. L. and Ruble, D. (2004). Children search for gender cues: cognitive perspectives on gender development, Current Directions in Psychological Science, 13(2), 67-70.

Maya, İ. (2013). Türk eğitim sistemindeki cinsiyet eşitsizliklerinin AB ülkeleri ile karşılaştırılması. Eğitim ve Bilim, 38(168), 69-84.

Miller, C. F., Lurye, L. E., Zosuls, K. M., and Ruble, D. N. (2009). Accessibility of gender stereotypes domains: Developmental and gender differences in children. Sex Roles, 60, 870-881.

Mirza, H. S. (1992). Young, female and black. London: Routledge.

Mitchel, A. (1995). Feminizm (Ş. Tekeli, Çev.). İstanbul: İletişim Yayınları. 
Nalbant, F. ve Korkmaz, T. (2019). Feminist teori temelinde toplumsal cinsiyet eşitliğinin Türkiye bağlamında değerlendirilmesi, AÇÜ Uluslararası Sosyal Bilimler Dergisi, 5(2), $165 \quad 186$.

Örs, H. B., (2016).19. yüzyıldan 20. yüzyıla modern siyasal ideolojiler, İstanbul, İstanbul Bilgi Yayınları.

Özdemir, H. ve Aydemir, D. (2019). Ekolojik yaklaşımlı feminizm/ekofeminizm üzerine genel bir değerlendirme: Kavramsal analizi, tarihi süreci ve türleri, Akdeniz Kadın Çalışmaları ve Toplumsal Cinsiyet Dergisi, 2(2), 261-178.

Powlishta, K. K., Sen, M. G., Serbin, L. A., Poulin-Dubois, D. and Eichstedt, J. A. (2001). From infancy through middle childhood: The role of cognitive and social factors in becoming gendered. In R. K. Unger (Ed.), Handbook of the psychology of women and gender (pp. 116-132). New York: Wiley.

Railton, D. and Watson, P. (2005). Naughty girls and red-blooded women: Representations of female heterosexuality in music video. Feminist Media Studies, 5(1), 51- 63.

Read, B. (2011). Britney, Beyoncé, and me-primary school girls' role models and constructions of the 'popular' girl. Gender and Education, 23(1), 1-13.

Ruble, D. N. and Martin, C. L. (1998). Gender development. In W. Damon (Ed.), Handbook of child psychology (5 ${ }^{\text {th }}$ ed., Vol. 3, pp. 933-1016). New York: Wiley.

Ruble, D. N., Martin, C. L., and Berenbaum, S. A. (2006). Handbook of child psychology. Gender development (6th ed., Vol. 3, pp. 858-932). Hoboken, NJ: Wiley and Sons.

Şahin, M. K., Çoban, A. E., ve Korkmaz, A. (2016). Toplumsal cinsiyet eşitliği ve türk eğitim sistemindeki yeri: okul öncesi öğretmen adaylarının gözünden. Uluslararası Bilimsel Araştırmalar Dergisi, 3(2), 735-752.

Sahin, I., Gülmez, Y., (2000). Efficiency of education: The case in Eastern and South-Eastern Turkey. Social Indicators Research, 49, 213-236.

Sani, F., and Bennett, M. (2001). Contextual variability in young children's gender in group stereotypes. Social Development, 10, 221-229. 
Sani, F., Bennett, M., Mullally, S. and MacPherson, J. (2003). On the assumption of fixity in children's stereotypes: A reappraisal. British Journal of Developmental Psychology, 99, $113-124$.

Sandelowski, M. (2000). Focus on research methods: Whatever happened to qualitative description?, Research in Nursing ve Health, 23, 334-340.

Sarıer, Y. (2010). Orta öğretime giriş sınavları (OKS-SBS) ve PISA sonuçları 1şı̆̆ında eğitimde fursat eşitliğinin değerlendirilmesi. Ahi Evran Üniversitesi Ĕgitim Fakültesi Dergisi, 11(3), 107-129.

Sayılan, F. (2012). Toplumsal cinsiyet ve eğitim: Olanaklar ve sinırlar. Dipnot, Ankara

Slaby, R. G., and Frey, K. S. (1975). Development of gender constancy and selective attention to same-sex models. Child Development, 52, 849-856.

Smits, J., and Gunduz-Hosgor, A., (2006). Effects of family background characteristics on educational participation in Turkey. International Journal of Eduational Development, $26,545-560$.

Strauss, A. and Corbin, J. (1990) Basics of qualitative research: Grounded theory procedures and techniques. London: Sage Publications.

Subrahmanian, R., (2005). Gender equality in education: Definitions and measurements. . International Journal of Eduational Development, 25, 395-407.

Tan, M. G. (2008). Türkiye’de toplumsal cinsiyet eşitsizliği sorunlar, öncelikler ve çözüm önerileri, TÜSİAD KAGİDER, İstanbul.

Tansel, A., (2002). Determinants of school attainment of boys and girls in Turkey: Individual, household and community factors. Economics of Education Review, 21, 455-470.

Taş, G. (2016). Fem inizm Üzerine Genel Bir Değerlendirme: Kavramsal Analizi, Tarihsel Süreçleri Ve Dönüşümleri. Akademik Hassasiyetler, 3(5), 163-175.

Temiz, Z., ve Cin, F. M. (2017). Okul öncesi eğitimde cinsiyet eşitliği üzerine betimsel bir çalışma. Yüzüncü Yıl Üniversitesi Eğitim Fakültesi Dergisi, 14(1), 940-965. 
Terzioğlu, F. ve Taşkın, L. (2008). Kadının toplumsal cinsiyet rolünün liderlik davranışlarına ve hemşirelik mesleğine yansımaları. C. Ü. Hemşirelik Yüksekokulu Dergisi. 12(2),62-67.

Thoits, P. A., and Virshup, L. K. (1997). Me's and we's: Forms and functions of social identities. In R. D. Ashmore and L. J. Jussim (Eds.), Self and identity: Fundamental issues (pp. 106-133). New York: Oxford University Press.

Ünlü-Çetin, Ş. (2016). Okul öncesi eğitim programı ile bütünleştirilmiş aile destek eğitim rehberi'nde (OBADER) toplumsal cinsiyet eşitliği vurgusunun baba katılımı özelinde incelenmesi, Current Research in Education, 2(2), 61-83.

Yağan-Güder, S. (2014). Okul öncesi dönemdeki çocukların toplumsal cinsiyet algllarının incelenmesi. (Yayımlanmamış doktora tezi). Hacettepe Üniversitesi, Sosyal Bilimler Enstitüsü, Ankara.

Yağan-Güder, S., ve Güler Yıldız, T. (2016). Okul öncesi dönemdeki çocukların toplumsal cinsiyet algılarında ailenin rolü. Hacettepe Üniversitesi Eğitim Fakültesi Dergisi, 31(2), 424-446.

Yıldırım, A. ve Şimşek, H. (2005). Sosyal bilimlerde nitel araştırma yöntemleri. Seçkin Yayınc1lık, Ankara.

Yılmaz, R. A. (2007). Reklamlarda toplumsal cinsiyet kavramı: 1960-1990 yılları arası milliyet gazetesi reklamlarına yönelik bir içerik analizi. Selçuk Üniversitesi İletişim Fakültesi Akademik Dergisi, 4(4), 143-155.

Zeyneloğlu, S. (2008). Ankara'da hemşirelik öğrenimi gören üniversite öğrencilerinin toplumsal cinsiyet rollerine ilişkin tutumları. (Yayımlanmamış doktora tezi). Hacettepe Üniversitesi, Sağlık Bilimleri Enstitüsü, Ankara.

Zucker, K. J., and Bradley, S. J. (1995). Gender identity disorder and psychosexual problems in $\quad$ children and adolescents. New York: Guilford Press.

\section{Summary \\ Problem Statement}

Gender roles are the products of culture in which we are living as our culture indoctrinate us about how women and men are looking, speaking or behaving. Based on social learning theory people learn these social gender roles by observing other people in society. 
While acquiring gender roles children first observe their family, immediate social environment and media. Then they put those behaviors in practice by modeling and imitating. Society's gender perceptions could be considered ideological. When people live, work and get education with the influence of predetermined gender ideology their beliefs and behaviors are shaped based on that ideology. The gender stereotypes reflect the perceptions of people who observe what other people do in their daily lives, as in all other social stereotypes. If we observe that a group of people perform a certain action in a long run, we believe that the skill and personality traits required to perform this action belong to that group. For example, if we consistently see women dealing with child care we believe that the characteristics of warmth and compassion for child care are specific to women. Owing to our gender stereotypes that we acquire by observing people we consider that women are capable of performing passive tasks and men are capable of performing more active tasks. Both media and our immediate environment play pivotal roles on the formation of these stereotypic beliefs. Women generally represented as making housework and dealing with their beauty instead of having professional occupation on advertisement. They generally are not shown as authority figure and they are kept in the background of men authority. As such, this study is seeking the answers for following questions:

1) What is pre-school children's gender stereotypes?

2) Is children's choice of profession that they plan to have in future influenced by gender stereotypes?

\section{Method}

Before commencing this study, official permission was taken from Ministry of National Education (MoNe). Ethical permission was also obtained from Yüzüncü Y1l Üniversity ethical committee as this study is conducted with 5 years-old children. Fifty ( 24 girls and 26 boys) five years-old children who were enrolling public pre-schools coming from low socioeconomic status families. Children were asked to evaluate their gender's positive and negative aspects. Following instruction was given to children:

"Hi I will ask you four questions. You are free to answer these questions. You would leave here if you feel uncomfortable. There is no right or wrong answer. I just wonder your ideas. There are two genders in the world as woman and man. It is same for 
children. Children are divided into two genders as girls and boys. For instance, you are boy/girl. What I will ask you is:"

What is the best aspect of being boy/girl?

What is the worst aspect of being boy/girl?

What profession would you plan to have in the future?

Why do you want to have this profession?

Fair copies of all interviews were prepared and organized for data analysis. Content analysis was utilized to analyses data. Open coding was embraced for coding. First of all, researchers read through raw data several times create tentative labels emerging from the data itself. Determining codes would help to compare relationships and finding similarities and dissimilarities in data. After that all codes and categories are gathered under the themes. Coding procedure was performed by two coders to ensure reliability of the study.

\section{Findings}

Five themes emerged from the study: Physical appearance, skills, personality traits, plays and choice of profession. Generally, girls associated their gender with physical appearance. Five girls stated that the best aspects of being girls is to have long hair and three girls expressed that they like being girls as they wear skirts and clothes. Children's attributions of skills to their gender is seem to influenced from gender stereotypes as nine girls attributed themselves passive skills such as being mother, helping mother and doing chores. While fourteen boys attributed themselves more active skills like driving and working. When we look at the personal traits, we again see the influence of social gender stereotypes. Three girls indicated that they like their gender as girls are well-behaved. On the other hand, boys embraced aggressive roles and four boys stated that being strong is the best aspect of their gender. Children's plays are also affected by social gender stereotypes since three girls said that they like their gender as they are able to play hopscotch and playing house. While boys preferred to play requiring movement and adventure like football. Children's choice of profession for future is also affected from social gender stereotypes. Girls mostly choose being teacher which is mainly performed by women in society. Similarly, boys declared that they choose police-officer and soldier which are characterized to men in society. When we look at the reason behind the choosing a profession, it is appeared that girls' choices originated from 
benefit of the society and people whereas the boys are making choices based on their interest, desires and skills.

\section{Conclusions and Recommendations}

It is appeared that gender stereotypes emerged as early as pre-school education. In order to accomplish social gender equity in society pre-school education is a good start. Teaching gender equity to children is a very complicated issue. It could not be established just being model to children. Some of the strategies that would be applied in class are to preventing gender discrimination among children, informing parents about gender equity, making children realize good aspect of their gender, preventing sexist discourse in class, removing sexist expression in children stories. 